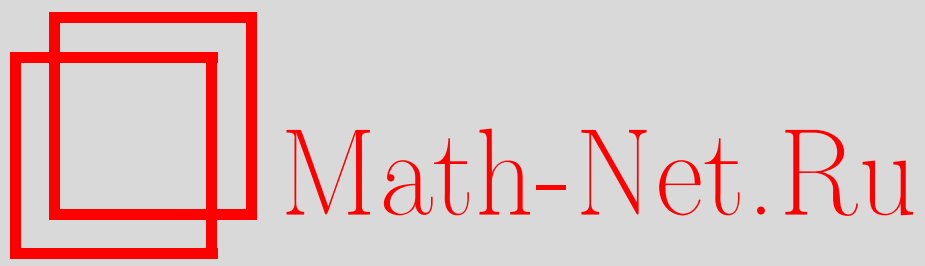

С. Дворянинов, Что такое шпунтик?, Квант, 2021, номер 9, 24-25

DOI: https://doi.org/10.4213/kvant20210903

Использование Общероссийского математического портала Math-Net.Ru подразумевает, что вы прочитали и согласны с пользовательским соглашением http://www .mathnet.ru/rus/agreement

Параметры загрузки:

IP : 54.210 .77 .194

26 апреля 2023 г., 14:11:11

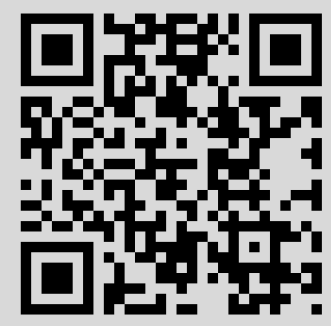




\section{Что такое шпунтик?}

\section{С.ДВОРЯНИНОВ}

$\Gamma$ А, ИМЕННО ЭТОТ ВОПРОС МОЖЕТ возникнуть у читателей замечательной книжки Николая Носова «Приключения Незнайки и его друзей». Герои этой сказки носят говорящие имена. Каждое имя указывает на характер персонажа или на род его занятий. Пилюлькин - врач Цветочного города, Тюбик - художник, Гусля - музыкант (гусли - это старинный музыкальный инструмент). Все ясно про Ворчуна и Молчуна. О любителях сладкого говорят имена Пончик и Сиропчик. Два друга Винтик и Шпунтик - изобретатели, мастера на все руки: и по металлу могут работать, и по дереву. С винтиком все понятно - это цилиндр с резьбой, который заворачивают и отворачивают отверткой, он служит для соединения различных деталей. Есть еще винт-пропеллер у самолета, гребной винт у моторной лодки. А вот со шпунтиком в повседневной жизни мы имеем дело не часто. Это уменьшительное слово происходит, очевидно, от слова шпунт. Вот о нем и поговорим.

Заметим сразу, что винтик - это отдельный предмет, он может существовать сам по себе. В упомянутой книжке потом появляются Шурупчик и Гвоздик. Можно подумать, что автор мог бы назвать коротышку Болтиком. Но корень этого слова - болт, и тогда сразу вспоминается глагол болтать, существительное болтун, имеющие негативный смысловой оттенок. Болтик не годится, и поэтому появился Шпунтик.

Шпунт - это выступ на ребре доски, который входит в соответствующий ему паз другой доски, который тоже называется шпунтом (рис.1). Доска со шпунтом называется шпунтованной. Такими досками настилают пол. Пол из отдельных досок в результате получается цельным. Даже если уложенные доски немного рассохнутся, то и в этом случае сквозных щелей не получится. Часто и сам этот способ соединения деталей назы-

DOI: https://doi.org/10.4213/kvant20210903

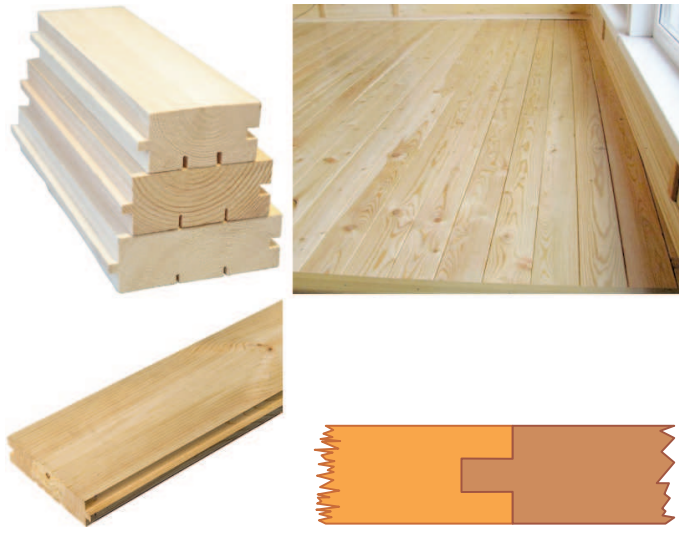

Рис. 1

вают шпунтом (немецкое слово Spund означает пробка, затычка).

Примечательно, что в наши дни на деле со шпунтом знакомы многие дети, играющие в лего (рис.2). Компания LEGO Group появилась в 1932 году. Ее основателем стал датчанин Оле Кирк Кристиансен, в то время работавший бригадиром плотников и столяров. Вот он и догадался сделать шпунтовое соединение основой столь популярной ныне игрушки.

Производственные мощности фирмы расположены в разных странах. Главный завод находится в Дании, где в цехах длиной до полукилометра стоят ряды автоматов, штампующих около 21 млрд кубиков в год. На это уходит порядка 60 тонн пластика в день.

Хорошо известно, что «Буратино» Алексея Толстого - это вариант книги Карло Коллоди про Пиноккио. Так и Винтик со Шпунтиком подтолкнули писателя Станислава Сахарнова написать свою сказку про двух других друзей-мастеров. В 1959 году была издана книжка «Гак и Буртик в стране бездельников», герои которой возвращаются в свою родную страну не на воздушном

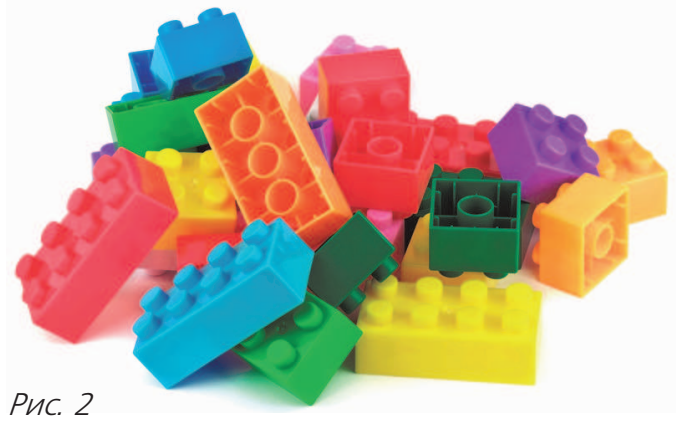






Рис. 3

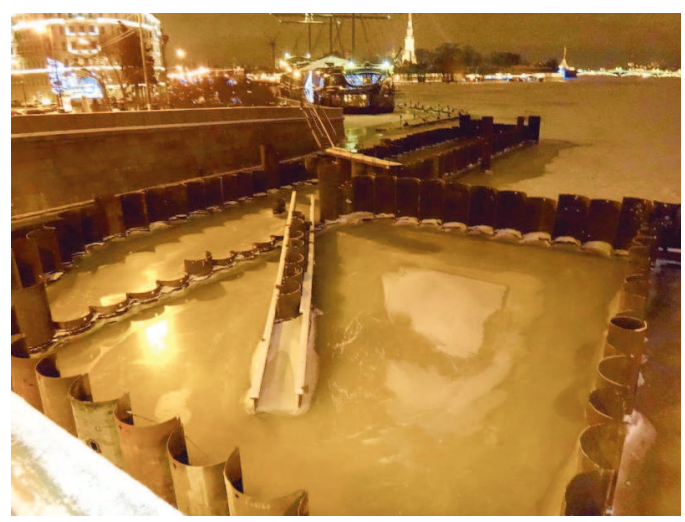

Pис. 4

шаре, а на построенной ими ракете. Имя Гак созвучно гайдаровским Чуку и Геку, а откуда Буртик? Предлагаем вам разобраться с этим самостоятельно.

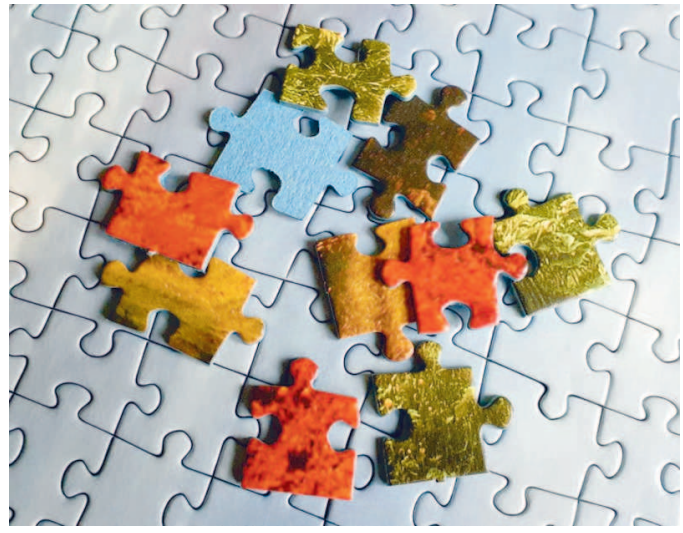

Рис. 5

Не надо думать, что шпунт распространился только на детские игрушки. С 1910 года в строительстве применяется шпунт Ларсена (рис.3). Все шпунтины здесь одинаковы, одна соединяется с другой замком, подобно тому как разомкнутые кольца соединяются в цепь любой длины. Если цепь натянута, то ни одно кольцо извлечь нельзя.

Шпунтом Ларсена укрепляют берега водоемов, насыпей, котлованов, он образует прочную вертикальную стенку (рис.4). При этом соединение отдельных шпунтин похоже на соединение кусочков пазла, когда один въезжает в другой (рис.5). Такие пазлы появились в 1909 году.

\section{В поисках}

\section{оптимальных построений}

\section{(из мемуаров барона Мюнхгаузена)}

Т РУЗЬЯ МОИ, ВЫ, БЕЗУСЛОВНО, наслышаны о моей любви к геометрии! А в геометрии - к задачам на построение. А в задачах на построение - к построениям наименьшим числом линий. Такие построе-

DOI: https://doi.org/10.4213/kvant20210904 ния часто называют оптимальными. Еще одна моя страсть - это путешествия на Луну! Во время таких путешествий я охотно рассказываю местным жителям о красивых задачах и теоремах геометрии, обучаю их оптимальным построениям.

Так, во время первого путешествия на Луну мы занимались построениями с помощью одной линии. Напомню, что задачи на построение выполняются циркулем и линейкой без делений, а линией называется прямая, луч, отрезок, окружность или ее частичка в виде засечки. Из построений одной линией жителям Луны особенно понравилась такая задача: на прямой $l$ отложен угол, равный $\alpha$ (рис.1), и надо одной линией построить угол, равный данному. Мы вместе 